\title{
EXTRA-PROVINCIAL LIABILITY OF THE LIMITED PARTNER
}

\author{
BRAD A. MILNE*
}

In recent years, the limited partnership has been seen as a particularly attractive investment vehicle in that it offers the limited partner both the security of limited liability, and the flexibility and relative informality of the partnership arrangement. More important however are the tax advantages. Unlike shareholders of a corporation, the individual partners are able to claim their portion of the income and losses of the partnership in accordance with the partnership agreement. A partner can set off against personal income the losses of the partnership, and claim any tax credits earned by the partnership for his own benefit. These tax advantages of the limited partnership are of particular interest to the oil and gas industry where substantial losses are of ten incurred over the initial period of exploration and development.'

The limited liability of the limited partner may however be in jeopardy where the limited partnership conducts operations outside the jurisdiction in which it was formed. In provinces and states where the relevant legislation has made provision for the registration of extra-provincial limited partnerships there is no question that the restricted liability of the limited partner will be maintained, ${ }^{2}$ but where registration is not possible without forming an altogether new partnership it is likely that the limited partner will be fully liable for the acts of the general partners. This article will analyze whether a third party who has been injured as a result of his dealings with a limited partnership outside a jurisdiction in which that limited partnership was either formed or registered may pursue an action against any of the limited partners without any restriction on their liability.

There are two situations in which a third party could seek redress against a limited partner but not rely on the laws of the jurisdiction of formation for his remedy. The first is where a contract is subject to the laws of a province or state in which the limited partnership is not registered. This difficulty may easily be avoided by simply inserting in the contract a proper law clause to the effect that the legal position of the limited partnership shall be subject to the laws of the place of formation.

- Barrister and Solicitor with Cook \& Milne, Calgary. The writer gratefully acknowledges the assistance of P.T. Farkas.

1. For a more expansive review of the investment advantages of the limited partnership, see Hepburn, Limited Partnerships (1983) I-14 to 1-27.

2. The provinces which provide for the registration of extra-provincial limited partnerships are British Columbia, Alberta, Ontario, Nova Scotia, Prince Edward Island, and most recently Newfoundland. It is interesting to note that the legislation of Ontario, Nova Scotia and Prince Edward Island have expressly given effect to the laws of the jurisdiction in which the limited partnership was formed so that the limited liability is maintained provided that the limited partnership has been registered. ISee Limited Partnerships Act, R.S.O. 1980, c. 241, s. 25(2); Partnerships and Business Registration Act, R.S.N.S. 1967, c. 225, s. 7(2); Partnership Act, R.S.P.E.I. 1974, c. P-2, s. 54.I(s)] It would appear therefore that in the absence of the adoption of foreign laws, either expressly as in the case of Ontario, Nova Scotia and Prince Edward Island, or implicitly by making provision for the registration of extra-provincial limited partnerships as in the case of British Columbia. Alberta and Newfoundland, the limited liability of the limited partner would be highly questionable. 
It is unlikely that a court would be sympathetic to the third party since he would have had no reason to believe that any of the limited partners would be personally liable for the debts of the partnership. The third party has entered into a contract with a partnership in which the limited partner has no control over managerial functions. Even his name is precluded from appearing in the partnership name. ${ }^{3}$ It is therefore difficult to see how a third party might be prejudiced by the limited liability of some of the partners. The second situation involves the third party who has been injured in tort. In these circumstances a court may be very sympathetic indeed, especially where the limited partner is the main impetus behind the operation which caused the injury and the general partner is merely a straw man or corporation established specifically for the purpose of management. ${ }^{4}$ Accordingly, the analysis in this paper will be of particular relevance where tortious acts have been committed by the partnership in a jurisdiction in which the limited partnership is not registered.

In order to properly evaluate the extra-provincial status of the limited partnership, it is imperative that its nature be fully canvassed. Since the liability of the shareholder of a corporation is generally limited regardless of the location of the corporation's activities, it is possible that an analogous argument can be made in respect to limited partnerships. This argument will be considered in Part I. Part II will attempt to analyze the extra-provincial transactions of the limited partnership from agency principles. Part III discusses the extent to which the courts of foreign jurisdictions, that is to say other provinces as well as foreign states, are likely to give effect to the limited partnership legislation in applying the law of the forum. Part IV reviews the legislative capacity of the provinces to extend the limited liability of the limited partner beyond provincial boundaries. Finally Part V illustrates some of the problems which may be encountered where the limited partnership engages in of fshore activities.

\section{THE CONCEPT OF PARTNERSHIP}

Why is it that a limited partner might not maintain his limited liability outside of the jurisdiction whereas the corporation is able to protect its individual shareholders from liability regardless of the location of the corporation's activities? The difference between the corporation and the limited partner is that the corporation is a legal entity separate from its members. It is therefore generally recognized that it is the corporation, as a legal person, which incurs the liability and not the shareholder. Whether any recourse is available against the shareholder is determined by the law of the jurisdiction of the corporation. Castel $^{5}$ argues that:

3. Partnership Act, R.S.A. 1980, chapter P-2, s. 53(1).

4. Where the limited partner is a director or officer of the general corporate partner he runs the additional risk of being held liable as a general partner even though it is the corporation through its officers and not the limited partner in his capacity as such which has participated in the control of the limited partnership. See Delaney v. Fidelity Lease Limited (1975) 526 S.W. (2d) 543; Mursor Builders v. Crown Mountain Apt. Assoc. (1978) 467 F. Supp. 1316; An excellent review of the authorities is contained in Robert D. Flannigan, "The Control Test of Investor Liability in Limited Partnerships" (1983) 21 Alta. Law. Rev. 303.

5. 2 J. G. Castel, Conflict of Laws, (1977) 311-12. 


\begin{abstract}
Questions concerning the status of a foreign corporation especially whether it possesses the attribute of legal personality, are, on the analogy of the human being governed by the law of the domicile of the corporation. The domicile is the state or province in which the corporation is incorporated. ...

The law of the state or province of incorporation determines whether the corporation has come into existence, its corporate powers and capacity and the persons who are entitled to act on its behalf. The law of the place of incorporation will also determine the rights of the shareholders of the foreign corporation.
\end{abstract}

Although the limited liability of the corporate shareholder is well settled under generally accepted principles of private international law, the extra-provincial application of the laws pursuant to which a partnership is formed is not at all clear. It may therefore be fruitful to analyze some of the fundamental differences between the common law partnership and the corporation in order to determine whether the limited partner might be able to claim limited liability by analogy with the shareholder of a corporation.

\title{
A. GENERAL PARTNERSHIP
}

A partnership is defined in the Partnership Act of Alberta as "the relationship that subsists between persons carrying on a business in common with a view to profit." 6 The basis of the relationship is contractual. Scamell and Banks, in commenting on the English statute in Lindley on Partnership, ${ }^{7}$ argue as follows:

Partnership, though of ten called a contract, is a relation resulting from a contract. The statutory definition does not state from what the relation arises, but that an agreement, express or implied, is the source of the relation was clearly established before the Act, and may be inferred from its provisions.

A corporation, on the other hand, is "in contemplation of a law a persona or entity distinct from the shareholders who comprise it. It is not like a partnership, a mere collection or aggregation of individual units."'8 Perhaps the most frequently cited judicial authority on the nature of the partnership is a passage from Farwell L.J.'s judgment in Sadler v. Whiteman ${ }^{9}$ where he observes:

In English law a firm as such has no existence; partners carry on business both as principals and as agents for each other within the scope of the partnership business; the firm name is a mere expression, not a legal entity . . It is not correct to say that a firm carries on business; the members of a firm carry on business in partnership under the name or style of the firm.

The only Canadian authority on the matter is In re Thorne \& New Brunswick Workmen's Compensation Board 10 where the New Brunswick Court of Appeal was required to determine whether a general partner could be employed by the partnership so that the partner might avail himself of workmen's compensation benefits. Since no person can possibly enter into a contract of employment with himself, counsel alleged that the general partner had entered into a contract of employment with the partnership and that the contract was therefore valid because the

6. Partnership Act, R.S.A. 1980, c. P-2, s. 1(d).

7. Lindley on Partnership, (14th ed. E.H. Scamell and R.C.P. Banks ed., 1979) 14.

8. Fraser \& Stewart, Company Law of Canada (1962) 18; See also Lindley on Partnership, supra n. 7 at 29-30; Beck, Getz, Iacobucci and Johnson, Business Associations Casebook (1979) 4-5.

9. [1910] 1 K.B. 868.

10. (1962) 33 D.L.R. (2d) 167. 
partnership was a legal entity distinct from its members. In support of this contention counsel placed considerable reliance on the decision of the House of Lords in Taff Vale Railway Co. v. Amalgamation Society of Railway Servants. ${ }^{11}$ Their Lordships concluded in that case that since the Legislature had granted trade unions the capacity to own property and to act through its agents, the Legislature must have intended unions to constitute a legal entity separate from their members and therefore be suable in law. The New Brunswick Court of Appeal had little difficulty in rejecting this argument and expressed the view that the partnership legislation was nothing more than a codification of the common law: ${ }^{12}$

Partnerships are an emanation of the common law, the term "firm" to describe the relationship having been borrowed from mercantile law. The Partnership Act, 1890 (U.K.) c. 39 is essentially a codification of the rules of common law and equity. Admittedly under such pre-existing rules no person could enter into a contract with himself or be his own employer and, as a partnership was regarded as having no legal existence distinct from the individuals comprising it, no person could be an employee of a firm of which he was a member.

The Court was of the view that the Legislature did not intend to endow partnerships with any new status: ${ }^{13}$

There is a fundamental distinction between the legislation involved in the Taff Vale and Therien cases and the Partnership Act of New Brunswick, as the latter does not purport to legalize or validate partnership firms, a status or condition already enjoyed by them under the common law. It is contended, however, that by its enactments relating to partnerships the Legislature has given them rights, powers and attributes not previously possessed and imposed on them duties and liabilities not previously existing which has resulted in their establishment under the law as legal entities. Support for the new concept is sought not only in the Partnership Act but also in O. 48a of our Rules of Court and certain dicta of Farwell $\mathrm{J}$., in the passages from his judgment in the Taff Vale case above quoted.

... An examination of the former Rules reveals that prior to the enactment in 1890 of the Partnership Act of the United Kingdom a partnership firm was in English jurisprudence recognized as an entity in the sense partners could sue or be sued in the firm name and execution issue against property of the partnership on a judgment against the firm. The earlier procedural provisions can have no greater significance or effect than they possessed before the Partnership Act of 1890 was enacted and, in our view, their incorporation into $0.48 \mathrm{a}$ in 1891 lends no support to the contention that Act created for partnership firms a new status.

The Court concluded that a trade union can be sued as a legal entity because it is a creature of statute whereas a partnership is not.

The only Canadian province in which a partnership may be considered a separate legal entity is Quebec. While no express statutory provision to this effect has been enacted, many of the doctrinal writers ${ }^{14}$ are of the view that the civil law system recognizes partnerships as separate entities. Mignault, ${ }^{15}$ for example, argues:

I think that, by making analogy with corporations, we can consider partnerships to be legal entities since these partnerships have a patrimony separate from that belonging to its members (translation).

11. [1901] A.C. 426.

12. Id., supra, n. 10 at 168.

13. Id. at 170-171.

14. See P.B. Mignault, Le droit civil canadien, Tome 8; Roche and Pare, Traite de droit civil du Quebec, Tome 13; E.C. Mark, "Partnership - The theory of the legal entity," Le droit civil francais (Barreau de Montreal, 1934); Goldwater, "La societe civile est-elle une personne morale?"' [1959-60] Themis 91.

15. Mignault, Le droit civil canadien, supra n. 14 at 186. 
Other writers are of the view that legal personality can only be conferred by statute. Baudry-Lacanterie ${ }^{16}$ argues:

Actually, it is certain that a collection of interests or individuals does not constitute civil personality in the absence of authority, or text of law . . . (translation).

The Quebec case law seems to illustrate that, provided a partnership has a commercial object, it will have a separate legal existence. ${ }^{17}$ However, the legal history of the civil law partnership is completely separate from its common law counterpart and therefore lends no assistance to our analysis.

\section{B. LIMITED PARTNERSHIP}

It is arguable that the legal status of the limited partnership may be different from that of the partnership. Limited partnerships did not exist at common law because mere participation in profits was sufficient to expose the investor to liability as a partner. ${ }^{18}$ Only with the enactment of The Limited Partnership Act, $1907^{19}$ did limited partnerships come into existence. Similarly, the various Partnership Acts suggest that a limited partnership only comes into being when the requirements of the Act have been complied with. Section 51(1) of the Alberta Partnership Act states that limited partnerships are not formed until a certificate has been filed, although section 4 lists a variety of circumstances in which a partnership may be found to exist notwithstanding a failure to file a declaration. Limited partnerships are "creatures of statute" because one must look to the provisions of statute for their validity. ${ }^{20}$

There is some judicial authority in the United States suggesting that firms which are creatures of statute must also be distinct entities. The leading case on the matter is $R$ uzicks $v$. Rager ${ }^{21}$ which states:

It is to be remembered that we are here concerned with a limited partnership. There is good reason for regarding such a partnership as a distinct entity for the purposes of pleading. Limited partnerships were unknown to the common law and, like corporations, are "creature[s] of statute" , Lanierv. Bowdoin, 282 N.Y. 32, 38, 24 N.E. 2d 732, 735. Statutes permitting limited partnerships are intended to encourage investment in business enterprise by affording to a limited partner a position analogous to that of a corporate shareholder. Due to the quasi-corporate aspects of a limited partnership and the quasi-shareholder status of a limited partner in that his liability is restructed to the amount of his investment and his voice in partnership affairs is negligible, it seems proper that in a suit by a limited partnership, the individual partners, whether general or limited, ought not to be subject to counterclaims against them upon causes of action unrelated to partnership affairs. The fact that a limited partner is not a proper party to actions by or against the partnership except where the action is brought to enforce a limited partner's rights against or liability to the partnership, gives added weight to that view.

16. Goldwater, supran. 14 at 91.

17. La cite de Montrealc. Gagnon (1904) 25 C.S. 178; Frenette et autres c. Aqueduc St. Gilbert (1931) 69 C.S. 167; Dupuis et autres c. Couture, [1958] C.S. 623; However Brown c. Taylor (1905) 28 C.S. 462 is inconsistent with these decisions.

18. This strict rule was however modified by the House of Lords in Cox v. Hickman (1860) 8 H. of L. Cas. 268.

19. $7 \mathrm{Edw} .7$, c. 24.

20. Hepburn, supra n. 1 at 1-1.

21. 305 N.Y. 191 (1953), 11 I NE 2d 878, 39 A.L.R. 2d 288; See also Millard v. Newmar and Co., 266 N.Y.S. 2d 254 (1966). 
This case does not appear to be in line with more recent authority, and in any event, can be distinguished in that the status of the partnership was being considered for procedural purposes only.

In Donsoy Ltd. v. U.S., 22 the United States Court of Appeal, 9th Circuit held that the legal status of a limited partnership was identical to that of a general partnership. On page 206 of the judgment the Court held:

[9] In the State of California, and, indeed, in Canada, a partnership, unlike a corporation, is considered to be not a legal entity, but an association of individuals. Our attention has not been called to any authority to the effect that a limited partnership in this respect is any different from a general partnership.

While the decision of the Court in Donsoy was concerned with whether a limited partnership was a separate legal entity for tax purposes and could therefore be restricted somewhat in its scope, Aikins J. of the British Columbia Supreme court considered the Donsoy case to be of general application in Skyline Associates v. Small and MacLeod. ${ }^{23}$

In Puerto Rico v. Russel and Co., ${ }^{24}$ the United States Supreme Court addressed the question of whether a sociedad en comandita, the equivalent of a limited partnership under Spanish law, was a separate legal entity. The Court took great care to distinguish this civil law concept from the common law limited partnership. On page 480, Stone J. held:

The tradition of the common law is to treat as legal persons only incorporated groups and to assimilate all others to partnerships. The tradition of the civil law, as expressed in the Code of Puerto Rico, is otherwise. Therefore to call the sociedad en comandita a limited partnership in the common law sense, as the respondents and others have done, is to invoke a false analogy. In the law of its creation the sociedad is consistently regarded as a judicial person.

The British courts have also refused to recognize in the limited partnership any legal status. In Re Barnard ${ }^{25}$ Farwell J. stated as follows: ${ }^{26}$

It is well settled that an ordinary partnership is not a legal entity like a limited company, and although the Limited Partnership Act, 1907, recognizes a limited partnership and requires it to be registered and gives liberty to inspect the register, it does not create it a legal entity. It is merely a combination of persons for the purpose of carrying on a particular trade or trades, and in no sense strictly speaking a legal entity.

The preponderance of case law therefore supports the contention that a limited partnership is not a separate legal entity. It appears, nevertheless, that the distinction made in $R e$ Thorne between partnerships and trade unions could not be applied to limited partnerships which, like trade unions, must rely on statute for their validity. The mere fact that limited partnerships owe their existence to the statutory provision is probably not sufficient to endow the limited partnership with the attribute of legal personality as suggested in Ruzicks unless it appeared that the Legislature clearly intended that the limited partnership should have a separate legal existence. A review of the various provincial statutes does not reveal any procedural advantages, rights or powers that are fundamentally different from those advantages enjoyed by ordinary partner-

22. 301 F. 2d 200 (1962); See also Puerto Rico v. Russell and Co. 288 U.S. 476 (1933).

23. [1975] I W.W.R. 385 .

24. Supran. 22.

25. [1932] 1 Ch. 269.

26. Id. at 272. 
ships. The legislation does not contain any provision resembling section 15 of the Canada Business Corporation Act ${ }^{27}$ which expressly states that a corporation has the capacity, both in and outside of Canada, of a natural person. It is therefore difficult to imagine that the Legislature intended to create a new category of legal entity.

\section{PRINCIPLES OF AGENCY}

A limited partner would not be able to claim immunity for the extraprovincial activities of the partnership by arguing that the limited partnership is a legal person and therefore responsible for its own liabilities. However, the limited partner is only a silent partner, a mere investor who does not participate in the management of the partnership. How is he privy to any contractual breach or tortious act of the partnership and in any way responsible for the acts of the partnership?

Liability will be imposed on the limited partner if he is considered a principal of the general partners. Section 6 of the Alberta Partnership Act states the common law position that "each partner is an agent of the firm and of his other partners for the purpose of the business of the partnership." The section makes no distinction between the limited and general partner. It would therefore appear that they are both principal and agent to one another. Hepburn ${ }^{28}$ characterizes this position under the Ontario Partnership Act as follows:

... In Ontario both the common law and legislation governing ordinary partnerships is applicable to limited partnerships to the extent that it is not inconsistent with limited partnership legislation. The Partnership Act of Ontario provides that every partner is an agent of the firm and his other partners. Thus, in an ordinary partnership, each partner is both principal and agent. In a limited partnership, a limited partner is a principal and, possibly to a limited extent, an agent.

The general partner is therefore acting as agent of the limited partner when he engages in activities under the firm's name.

Although the limited partner may be a principal to the general partners, his liability is nevertheless limited by statute. Section 48 of the Alberta Partnership Act clearly qualifies the provisions relating to ordinary partnerships including the relationship between the parties by stating that these provisions are to be read subject to the provisions contained in that part dealing with limited partnerships. Section 63 states that a limited partner will not be liable for the affairs of the partnership provided that he does not participate in the control of the business. Therefore, notwithstanding the position of the limited partner as principal, his exposure to liability has been expressly restricted by the Legislature.

Although section 63 clearly acknowledges the limited liability of a limited partner notwithstanding his position as principal, the relationship of agency may still affect his liability towards third parties. Section 63 will apply to all third parties who seek to rely on the laws of Alberta to enforce their claims. The problem arises when the act complained of is subject to the laws of another jurisdiction. For example, where a court in

27. S.C. $1974-75$, c. 33 , as am.

28. Supran. I at II-45. 
Saskatchewan is called upon to apply the laws of Saskatchewan in relation to a tort which has occurred within that province, it is unlikely that the third party who has not otherwise assented to the laws of Alberta will be subjected to the provisions of the Alberta Partnership Act.

The relationship between limited and general partners will generally be determined according to the jurisdiction in which the partnership agreement was formed, unless otherwise intended by the parties. ${ }^{29}$ It is clear that the liability of the limited partner will remain limited vis-a-vis the general partners, notwithstanding the foreign activities of the partnership. However, the liabilities of the principal as regards third parties are governed by the proper law of the contract between the agent and third party, or in the case of a tort, the place where the negligent act occurred. ${ }^{30}$ If the contract is entered into in another jurisdiction and the parties have neglected to insert a proper law clause, or the partnership is negligent outside the jurisdiction, then the limited partner as principal will be subject to the laws of that jurisdiction.

It is sometimes difficult to ascertain whether the matter in dispute relates to the relationship between principal and agent or principal and third party. In Ruby S.S. Corp. v. Commercial Union Assurance Co., ${ }^{31}$ a New York firm of insurance brokers engaged an agent to enter into an insurance policy in England on their behalf. The assured then brought an action against the English underwriter notwithstanding that the broker had ceased paying premiums. The question for determination was whether the broker could cancel the policy without the consent of the assured. The English Court of Appeal decided that since under the laws of New York the broker was free to do so and had therefore validly terminated the contract, the assured could not succeed in its claim. Dicey and Morris argue that the effect of this decision is to apply, contrary to conflicts of law principles, the proper law of the agency to the contract concluded between an agent and third party. However, in determining which law was to apply the court was concerned not with the terms of the policy of insurance contracted between the agent broker and third party underwriter, but with the authority of the agent to cancel the policy without consent under its contract of employment. Scrutton L.J., with whom Romer and Greer L.JJ. concurred, held; ${ }^{32}$

The employment of the American broker is in the United States to do an act there which will result in the underwriting of a policy in England. The questions then arise: (I) What law is applicable to the employment as between broker and employer? ...

As to the relevant law, I follow and agree with the dictum of Lindley L.J. delivering the judgment of the Court of Appeal in Maspons v. Mildred (9 Q.B.D. at p. 539), that in considering the nature and extent of the authority given by a Spanish principal to a

29. Dicey \& Morris, The Conflict of Laws, (10th ed., 1980) 909-11; Cheshire and North, Private International Law, (10th ed., 1979) 239. However there are several cases where the courts have looked to the jurisdiction in which the parties intended the agreement to be executed and not the jurisdiction in which the agreement to be executed and not the jurisdiction in which the agreement was entered into. See Chatenay v. Brazilian Submarine Telegraph Company [1981] 1 Q.B. 79; Pinney v. Nelson 183 U.S. 144 (1901); Thomas v. Matthiessen 232 U.S. 221 (1914).

30. Dicey \& Morris, The Conflict of Laws, supra 29 at 911 ; see also Maspons v. Mildred (1882) 9 Q.B.D. 530 (C.A.).

31. (1930) 150 L.T. 38, [1933] Al] E.R. Reprint 711.

32. Id. at 713 (All E.R.). 
Spanish agent in Spain (Cuba) the Spanish law is to be taken into account. The principle as stated by Professor Dicey in his second edition of the Conflict of Laws - I am reading from section 179 in the Fifth Edition, it is another rule in the second edition -

"The agent's authority as between himself and his principal is governed by the law with reference to which the agency is constituted, which is in general the law of the country where the relation of principal and agency is created,"

and this rule has been continued unchanged by later editors. To find the authority as between Johnson and Higgins, and their principals Williams \& Co. and/or Ruby, I, therefore, look to the law of the State of New York, where the employment took place.

The $R u b y$ case illustrates the difficulty in characterizing whether the question relates to the authority of the agent which is determined by the law of the agency, or the terms of the contract between the agent and third party which will be determined by the proper law of the contract.

This confusion becomes particularly acute when the agent general partner contracts out of the jurisdiction. Is his authority to bind the limited partner principal restricted to the extent of the limited partner's contribution? This was the rationale behind the decision of the New York Court of Appeal in King v. Sarria, ${ }^{33}$ where a Cuban limited partnership was sued in New York upon a contract made in New York by the general partner on behalf of the firm. On the issue of the liability of the limited partner, the Court held: ${ }^{34}$

\footnotetext{
... that any restriction which by agreement amongst the partners is attempted to be imposed upon the authority which one partner possesses as the general agent of the other, is operative only between the partners themselves, and does not limit the authority as to third persons, who acquire rights by its exercise, unless they know that such restriction has been made. It is manifest, however, that this remark is to be qualified, when taken in connection with any statute law, which has provided for the formation of limited partnerships, where that statute law is operative. A due observation of such statutory provisions limits the liability of the special partner, and fixes beforehand the extent to which, as agent, he may bind the special partner. It is hardly necessary to say, that when a limited partnership is duly formed, and carried on under our statute, though the general partner is the agent for all the partners, with powers full enough to transact all the business of the firm, and to bind it to all contracts within the scope of that business, he gets no authority, from his relation as partner and agent of the special member of the firm, to fix upon him any greater liability than that which has been stipulated for.
}

A closer analysis will reveal that it is not the authority of the general partner which is limited, but the responsibility of the limited partner for the authorized acts of the partnership. A limited partner may say to the general partner agent that he must only enter transactions within the objects of the agreement and that the limited partner will not be responsible for transactions not authorized. This would be a term concerning the employment of the agent, and on the basis of Ruby S.S., would be subject to the laws of the jurisdiction in which the agency or partnership agreement was contracted. However, it is something else to say "I authorize you to enter into these transactions, but not to render me liable in excess of my investment." In this latter case, the general partner enters into an authorized transaction with the third party on behalf of the limited partnership. The limited partner cannot restrict his liability to the third party who is not privy to this condition. It is one thing to limit the authority of an agent, it is another to limit the consequences of the authorized acts of that agent.

33. 69 N.Y. 24 (1877), 25 Am. Rep. 128.

34. Id. at 28-9. 


\section{EXTRA-PROVINCIAL RECOGNITION}

\section{A. RECOGNITION GENERALLY}

A second basis for the Sarria decision was that foreign legislation which purported to bind third parties to the limited liability provision in the partnership agreement should be recognized where it is not inconsistent with the public policy of the local jurisdiction; 35

\footnotetext{
But it is claimed by the learned counsel for the plaintiff that the Commercial Code of Spain cannot have an extra-territorial effect; and that one dealing in this State, in which that law does not rule cannot avail himself of its elect . . But one country recognizes and admits the operation within his own jurisdiction, of the laws of another, when not contrary to its own public policy, nor to abstract justice, nor pure morals. It does this on the principle of comity ... The principle, from which originates the influence exercised by the law of a foreign State, in determining the status or rights of its subjects in another country, is thus well stated. It is the necessary intercourse of the subjects of independent governments, which gives rise to a sort of compact, that their municipal institutions shall receive a degree of reciprocal efficacy and sanction within their respective dominions. It is not the statutes of one community which extend their controlling power into the territories of another; it is the sovereign of each who adopts the foreign rule, and applies it to those particular cases in which it is found necessary to protect and cherish the mutual intercourse of his subjects, with those of the country whose laws he adopts: It cannot be said that there is a rule of exclusion, on account of this particular law being contrary to our public policy. It much resembles our own statute for the formation of limited partnerships, and with some difference in detail, it aims at the same beneficial result, which ours has in view; nor may we say with our statute before us, that the law is opposed to good morals or abstract justice.
}

In Barrows v. Downs ${ }^{36}$ and Lawrence v. Batcheller ${ }^{37}$ the courts were also ready to give effect to the foreign legislation where the legislation of the forum was similar in substance.

The common law approach to recognition of foreign legislation is more stringent. In Bank voor Handel v. Slatford ${ }^{38}$ the Netherland Government issued a decree which purported to make restitution to a bank carrying on business in Holland of the proceeds of the sale of gold which had been entrusted by the government (when in exile in London during World War II) to the Custodian of Enemy Property. The Custodian argued that the Dutch legislation was without ef fect in England. The bank argued that legislation of a foreign State affecting the title of its own nationals to personal property located in England should be given effect where the legislation is neither contrary to public policy nor contrary to English legislation. Devlin J. was of the opinion that he could not give effect to the legislation: ${ }^{39}$

There are other considerations of principle which can be advanced in support of the defendants' argument. First, in construction of our own statutory legislation we accept the principle that, unless the contrary is made clear, an Act of Parliament is not intended to have extra-territorial effect. Secondly, the principle, as submitted by the defendants, is in harmony with the principle which favours the lex situs generally. Thirdly, if extra-territorial effect is given to foreign property legislation, it can only be at the expense of English law affecting the same subject-matter. This seems to me a point worth detailed consideration. The plaintiffs do not suggest that such legislation could override the express provision of an Act of Parliament. While, however, it is easy to concede that
35. Id. at 30-1.
36. 11 Am. Rep. 283 (1870).
37. 131 Mass. 504 (1881).
38. [1951] 2 All E.R. 779.
39. Id. at 787. 
some limits would have to be imposed, it is not so easy to define what they should be. No foreign legislation could have any effect at all unless the common law, by which, ordinarily, rights of property are governed, is subordinated to it.

It is unlikely that a court would be eager to give effect to the limited liability of a limited partnership formed under foreign legislation because the effect would be to undermine the common law. Persons of the forum would have their civil rights subjugated to the terms of the partnership agreement and sanctioning legislation. However, in General Steam Navigation Co. v. Guillou, ${ }^{40}$ two of the five judges were willing to give effect to such legislation. In that case the defendant was sued personally when a ship, through the negligence of its mariners, collided with an English ship on the high seas. The defendant argued inter alia that he did not own the ship but that he was merely director and shareholder of a society or company established pursuant to French laws which did own the ship and was therefore not responsible for the acts of the mariners. Parke B, who delivered the judgment of the court, held; 41

The injury complained of is averred to have risen on the high seas, out of the jurisdiction of England, and not to have been committed by the defendant personally, but by a third person, who was master of a French vessel, the defendant being a French subject . .. If the defendant was not liable for the acts of that other by that law which is to govern this case, he has a good defence to the action; and, for the defendant, it is contended that the pleas means to aver that, by the law of France, he was not liable for these acts, but that a body established by the French law, and analogous to an English corporation, were the proprietors of the vessel, and alone liable for the acts of the master, who was their servant, and not the servant of the individuals comprising that body; and, if such be the true construction of this plea, we are strongly inclined to think that there is a good defence to this action. On the other hand, the plaintiffs contend, that the plea only means, that in the French Courts the mode of proceeding would be to sue the defendant jointly with the other shareholders of the company under the name of their association; and, if this be the true construction of the plea, we all concur in the opinion that the plea is bad; for it is well established, that the forms of remedies and modes of proceedings are regulated solely by the law of the place where the action is instituted - the lex fori and it is no objection to a suit instituted in proper form here, that it would have been instituted in a different form in the Court of the country where the action arose, or to which the defendant belong.

Although the Court was divided on the issue of whether the law of France was procedural or substantive in nature, the court was willing to give effect to the substantive laws of France concerning the firm. It also appears from this passage that the Court was of the view that the firm constituted a "third person", "analogous to an English corporation", and may have been willing to give effect to the limited liability on that basis. It should also be noted that the event occurred on the high seas and not within English territory where presumably English law, both procedural and substantive in nature, would have been applied. ${ }^{42}$

40. (1883) $11 \mathrm{M} \& \mathrm{~W} 877$.

41. Id. at 894 .

42. There are in fact several other cases which deal with the ability of a third party to seek redress against the partners of foreign limited partnerships. See Re Doetsch, Matheson v. Ludwig (1896) 2 Ch. D 836; The M. Moxam (1876) 1 P.D. 107, [1874-80] All E.R. Reprint 679. However the cases are not pertinent to our analysis since the wrongs complained of occurred in foreign jurisdiction where the liability of the partner was limited. In these cases the court was willing to apply the substantive law of the place where the act occurred on the basis of Phillips v. Eyre. In Bullockv. Caird (1875) 10 L.R.Q.B. 276 and Van Hellfeldv. E. Rechnitzer and Mayer Freres \& Co. [1914] I Ch. 748 the courts refused to give recognition to the foreign law restricting liability which was considered to be a matter of procedure to which the laws of the forum are applied irrespective of where the act complained of occurred. 
It does appear, however, that the common law will give effect to the legislation of the jurisdiction of formation where the partnership is a separate legal entity. In the decision of the Ontario Court of Appeal in Henderson v. Strang, ${ }^{43}$ the defendant William Strang had agreed to purchase shares in an Ontario corporation, the money for which being deposited with the firm of William Strang \& Son to finance the corporation's purchases in Europe. An action was brought by a minority shareholder to compel Strang to pay the amount owed on the shares arguing that the entire transaction contravened the Canadian Companies Act in that the shares were not paid-up. Meredith C.J.C.P. and Britton $\mathrm{J}$. were of the view that the agreement was ultra vires the company and therefore Strang was not liable, but held that even if the agreement was intra vires, the deposit with William Strang \& Son constituted a loan made to the partnership which was separate from the shareholder. Riddell J. held that the agreement was intra vires, but had this to say with regard to the foreign recognition of the limited partnership: ${ }^{44}$

\begin{abstract}
We need not consider what the legal status of a partnership and its members might be in the absence of a statute. The Imperial Act, 1890, 53 \& 54 Vict. ch. 39 sec. 4(2) expressly enacts: "In Scotland a firm is a legal person distinct from the partners of whom it is composed" (This is but a restatement in statutory form of the Common Law of Scotland, which differs from ours. See Bell's Principle of the Laws of Scotland). The status of a partnership in Scotland determines its status in Ontario. The Courts have not been quite uniform in decision but a comparison of more or less recent cases exhibits a distinct and increasing tendency on the part of English Courts to approximate in practice to the theory that a person's status is governed by his lex domicilii.
\end{abstract}

The decision was subsequently appealed to the Supreme Court of Canada, ${ }^{45}$ where the decision of the Court of Appeal was affirmed on other grounds. Mignault however agreed that Strang \& Co. was a distinct legal entity separate from Strang, and therefore the shares had been validly paid for ${ }^{46}$

\title{
B. DISTINCTION BETWEEN STATUS AND INCIDENTS OF STATUS
}

It would appear that if a court were prepared to recognize the partnership as a separate legal entity where this attribute has been conferred upon it by the jurisdiction of formation, a partner would escape liability because he has not entered into the transaction either personally or as principal. This position may be consistent with case authority, although it is unclear from a policy point of view why a court should recognize the limited liability of a legal entity and not do so where a separate status has not been conferred upon the partnership? In both cases the court would be giving effect to foreign legislation within its own jurisdiction.

The distinction is explained by the principles of public international law as developed through the comity of states. Under these principles, the legislative jurisdiction of a state is absolute and exclusive within its territory. ${ }^{47}$ The principle of sovereignty does not require one state to

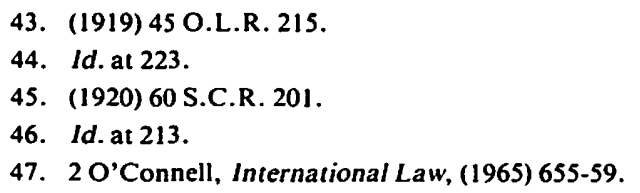


recognize the legislation of another state insofar as it affects the rights of its own citizens. Although a court will generally apply the law of the jurisdiction where a contract is formed, a marriage is celebrated, or an accident occurred because the act happened in that jurisdiction, it is not bound to recognize the laws of the foreign jurisdiction where the act occurs on its own territory. However, to proceed strictly on this basis would not be conducive to the mutual interests of states in retaining some degree of control over their nationals when they go abroad. In order to permit the domiciliary state to retain some control over its residents, a distinction of status versus incidents of status has evolved, the rationale being that the state of domicile has a much greater interest in ensuring that its subjects conform to the laws that regulate the status or "legal position or condition of a person in or with regard to the rest of the community" 48 in which he is domiciled. As an expansion of the principle, nations have endowed certain legal fictions with the attribute of personality and similarly have an interest in ensuring that their status is within the regulation of the state of domicile. The analysis offered by Ritchie C.J.C. in C.P.R. v. Western Union Telegraph Co. ${ }^{49}$ has of ten been cited in this regard:

The comity of nations distinctly recognizes the right of foreign incorporated companies to carry on business and make contracts outside the country in which they are incorporated, if consistent with the purpose of the corporation, and not prohibited by its charter, and not inconsistent with the local laws of the country in which the business was carried on, subject always to the restrictions and burthens impressed by the laws imposed therein; for there can be no doubt that a state may prohibit foreign corporations from transacting any business whatsoever, or it may permit them to do so upon such proper terms and conditions as it may prescribe.

A state will generally give recognition to foreign laws affecting the status of a foreign entity although it will not give ef fect to the rights and obligations conferred by foreign law. The distinction in regard to liability for debts was discussed in National Bank of Greece and Athens v. Metliss. ${ }^{50}$ In that case, the National Bank of Greece had guaranteed bonds issued by another Greek bank to the plaintiff, a term of the bonds being that they were to be subject to the laws of England. A moratorium suspending payment on the bonds was enacted in Greece and was still in force at the time the plaintiff issued the writ. Subsequent to the enactment of the moratorium it was also decreed that the National Bank of Greece and the Bank of Athens should be amalgamated assuming all the assets and liabilities of both banks. The questions before the House of Lords were:

1. Whether effect would be given to the Greek decree whereby the National Bank of Greece and Athens assumed the obligations of the National Bank of Greece;

2. Whether the claim could be barred by the Greek moratorium.

On the first question, it was contended by counsel for the bank that the liability conferred upon the bank by the decree was not an element of

48. Niboyet v. Niboyet(1878) 4 P.D. 1 at 11 (per Brett L.J.).

49. (1890) 17 S.C.R. 151 at 155.

50. [1958] A.C. 509. 
status, but an obligation and therefore an English court should not give effect to the Greek law. In reply Lord Tucker held:51

\begin{abstract}
English law will look at the decree to determine the status of the new entity. It is contended however, that the transfer of liabilities from the old bank to the new is no part of its status. It is said that status is confined to the existence, powers and dissolution of the new corporation ...

In my view the fact that liability was attached to it at birth by its creator can properly be regarded as a matter pertaining to the status of the appellant company and accordingly, governed by the law of its domicile.
\end{abstract}

In answer to the second question it is perhaps best to refer to a passage in the judgment of Lord Denning in the Court of Appeal which was quoted in part by Lord Tucker in the House of Lords: ${ }^{52}$

The defendant company says that if the English courts recognize the Greek law so as to make it liable as a universal successor, so also they should recognize the Greek law of moratorium. The English courts cannot it is said, when dealing with the liability of the defendant company, take the Greek law in part and reject it in part ...

This is a forceful argument, but I do not think we can give effect to it. The rules of private international law do not permit it. The debtor is a Greek debtor but the debt is an English debt. When we are considering the personality of the debtor or succession to his personal effects, we must apply Greek law because he is a Greek; but when we are considering the amount of the debt and the obligation to pay it, we must apply English law because it is an English debt. If the old National Bank of Greece had continued in existence, the English courts would give judgment against the company for immediate payment without regard to the moratorium. Greek law has destroyed the old National Bank of Greece and has set up a new company in its place. We recognize that the Greek law has the power of life and death over the company which it created, and we must accept the substitute which it has provided. But when the substitute stands in our courts to answer an English debt, it must answer according to English law . . . (emphasis added).

The Court was willing to apply Greek law insofar as it affected the status of the Greek entity, but it ignored the moratorium, the purpose of which was to limit the liability of the bank for acts which were subject to the laws of England.

If a jurisdiction will only recognize foreign legislation which affects the status of a subject whether legal or natural, and a partnership cannot possess "status" because it is merely the result of a contractual arrangement and not a legal entity, could the limited partner not argue that the legislation of his domicile has limited his liability by virtue of his status as a limited partner? This argument has been expounded by Hepburn: ${ }^{53}$

Despite the relatively simple use of the concept, a limited partner may wish to argue that "the state", Ontario, has conferred upon him a "status", just as in marriage, the state confers upon an individual the status of husband or wife with its attendant rights and obligations. The limited partner might further argue that his status as a limited partner should be recognized throughout the country, with the possible exception of Quebec, along with the attendant rights and obligations.

Hepburn is also aware of the difficulties with this approach. He continues:

However, assuming that a limited partner was successful in arguing that he had the status of limited parnter and, that applying the above-noted conflict principles, this status was recognized in a foreign jurisdiction, the limited partner would not necessarily at that point be assured of the Ontario Act's protection. Although foreign courts generally recognize a status conferred by the lex domicilii, they exercise a discretion in

51. Id. at 529.

52. [1957] 2 Q.B. 33, at 46.

53. Hepburn, Limited Partnerships, supra 1 at II-44. 
giving effect to the incidents of status. In view of this Castel argues that an individual's capacity to enjoy and exercise rights cannot be determined by reference only to the laws governing his status.

It would be useful to elaborate on this distinction. The passage of Castel referred to by Hepburn is as follows: 54

It is important to distinguish between status and the incidents of status, since all or any of the incidents which attach to a particular status by virtue of the lex domicilii may not be recognized everywhere.

In other words, "the recognition in X of the existence of the status created by the law of $Y$ and the giving effect to its incidents are separate questions, so that, for example, a person may have the status of legitimate or legitimated child and, as an incident of that status, be entitled to claim in the character of child by the law of $Y$, and be recognized as a legitimate or legitimated child in $X$, and yet not be entitled to claim under the succession law of $X$ because he is not within the definition of child in that law". The difficulty is whether the Courts should decide a question involving the incidents of status without making a preliminary determination as to the existence of such status.

As authority for this proposition Castel cites Falconbridge, ${ }^{55}$ as well as the American Restatement, ${ }^{56}$ which he quotes to the effect that ". . . the incidents that arise from a status are likely to vary since they depend upon the law governing the particular incident."

A similar distinction is also offered by McLeod: ${ }^{57}$

In an attempt to balance the interests of the forum and the domicile in the area of status, the Courts have adopted an uncomfortable and sometimes uncertain compromise. By reference to the notion of vested rights, the Courts have held that the existence of a status imposed by the law of a person's domicile ought generally to be recognized by all countries. The Courts of other countries may, however, exercise their discretion in giving effect to the results of such status. Any or all of the incidents of a particular status imposed by the lex domicilii may not be recognized in other jurisdictions.

While McLeod does not approve of this distinction he does not contest its existence in law. He continues:

It is becoming increasingly accepted that the concept of status should no longer be regarded as a separate and independent legal issue. Although the rule in its present form has been endorsed by a number of writers and courts, it is suggested that the rule is no more than a recognition that most aspects of a person's status are regulated in some manner by the lex domicilii. Any attempt to isolate a general law of status accomplishes very little in the abstract and confuses the issues in particular cases which bear upon a person's personal characteristics. Status involves belonging to a particular class to whom the law assigns certain incapacities and yet it is clear that the question of capacity, as it pertains to a particular transaction, is determined without reference to the legal issue of status.

The approach of the courts to this distinction is perhaps best illustrated in Re Langley's Settlement Trusts; Lloyds Bank v. Langley, ${ }^{58}$ where a settlement, the proper law of which was English law, allowed the settler to withdraw during his lifetime any part of the trust fund provided that the capital remain above a certain value. The settlor, whose domicile was California, was incompetent pursuant to the laws of that state and could not under Californian law exercise the power of withdrawal. The English Court of Appeal, in deciding whether there had been a valid exercise of
54. J.-G. Castel, Conflict of Laws, supra n. 5 at 42.
55. Falconbridge, Essays on Conflict of Laws, (2nd ed., 1954) 754.
56. 2 American Restatement of the Law (Second), Conflict of Laws 232.
57. MacLeod, The Conflict of Laws, (1983) 237.
58. [1962] Ch. 541 . 
the power of withdrawal, held that while they would recognize the status of the settlor as an incompetent, they would not give effect to the incidents of that status under the laws of California. Lord Evershed M.R. held:59

\begin{abstract}
We were very properly referred to the passages in the classic book, Dicey's Conflict of Laws, 7th ed. (1967), and particularly chapter 10 devoted to status and rules 28 and 29. Rule 28 at page 223 reads: "Subject to rule 29 , the existence of a status under the law of a person's domicile is recognized by the Court, but such recognition does not necessarily involve giving ef fect to the results of such status." I read at once rule 29 , which is: "The Court will not give effect to the results of a status existing under a foreign law which is penal." To rule 29 I will revert presently, but the editors, under the comments which follow rule 28 , refer to certain views or theories taken in regard to the acceptance as a matter of private international law by the Municipal Courts of England of the effects of status under the law of some persons' domicile, and a third view, which is favoured by the editors and which, as I conceive, justified the last two lines of the rule I have read, is stated thus at page 225: "The existence, at any rate, of a status imposed by; the law of a person's domicile ought in general to be recognized in other countries, though the courts of such countries may exercise discretion in giving operation to the results of such status." I take that passage and the statement of the rule itself in the last two lines, which I repeat, "But such recognition does not necessarily involve giving effect to the results of status," with the passage which 1 have read from the judgment of Lord Green, M.R. as justification for the conclusion, if it be necessary to rest it on this basis, that albeit the settlor was decreed an "incompetent" and had what one might like to call the status of an incompetent according to the country of his domicile, nevertheless the court will not necessarily give rigid, indeed I might say cynical, effect to all the consequences of such a conclusion where the result would be that (let me observe, in flat contradiction to the express purpose of the Californian order) to deprive the settlor of the right he has under this settlement.
\end{abstract}

It is therefore submitted that a court will not easily accept the idea that limited liability is part of the status of a limited partner. As illustrated above by both Castel and McLeod, status involves belonging to a particular class to which the law assigns certain capacities and incapacities. However, even if a foreign jurisdiction should recognize the status it may not give effect to the rights and obligations which the jurisdiction of domicile attaches to the status. Therefore, if a limited partner were successful in arguing that he is part of a class of persons distinct from the general community in which he lives, and that his limited liability is something more than a right which has been contracted through the partnership agreement, a foreign court may be willing to recognize his status and yet not gives effect to the rights and obligation which the domiciliary jurisdiction attaches to the status.

\title{
IV. CONSTITUTIONAL IMPEDIMENTS
}

Even if the courts of another province or foreign jurisdiction were otherwise prepared to acknowledge the limited liability of a limited partner, there is also the constitutional impediment which precludes provincial legislation from having any extra-provincial effect. Section 92(13) of The Constitution Act, $1867^{60}$ confers upon the provinces jurisdiction over "Property and Civil Rights in the Province" (emphasis added). A discussion of relevant judicial authorities will show that the courts have interpreted these last three words very strictly.

59. Id. at 554-55.

60. $30 \& 31$ Victoria, c. 3. 
The most frequently cited authority is Royal Bank of Canada v. King. ${ }^{61}$ In that case, the Alberta government expropriated the proceeds of a bond issue which had been issued by a defaulting Alberta railway company and had agreed to assume the liabilities of the company on the issue. However, since the proceeds of the issue were being held in a bank located outside the province, the Privy Council felt that Alberta was without legislative jurisdiction. ${ }^{62}$

\begin{abstract}
In the opinion of their Lordships the effect of the statute of 1910, if validly enacted, would have been to preclude the bank from fulfilling its legal obligation to return their money to the bondholders, whose right to this return was a civil right which had arisen, and remained enforceable outside the province. The statute was on this ground beyond the powers of the Legislature of Alberta, inasmuch as what was sought to be enacted was neither confined to property and civil rights within the province nor directed solely to matters of merely local or private nature within it.
\end{abstract}

The Alberta Court of Appeal has followed this argument on two occasions. In Credit Foncier Franco-Canadien v. Ross, ${ }^{63}$ an Alberta statute which purported to affect the interest on debts payable outside the province was held to be ultra vires. Notwithstanding that the legislation applied where the debtors were resident in Alberta, the Court was of the view that the debt was payable outside the province and was therefore a civil right outside the province. In the more recent division of Regina $\mathrm{v}$. Thomas Equipment Ltd. ${ }^{64} \mathrm{McGillivray} \mathrm{C.J.A.} \mathrm{and} \mathrm{Cavanagh} \mathrm{J.A.} \mathrm{held}$ that a provision of the Farm Implement Act which required a vendor to repurchase unused farm machinery when so requested by the purchaser had no effect where the vendor was a resident of New Brunswick and not carrying on business within Alberta since the failure to purchase the machinery occurred outside the Province of Alberta.

However, the Supreme Court of Canada has recently been divided on this issue. In Interprovincial Co-Operative Ltd. et al v. The Queen in Right of Manitoba, ${ }^{65}$ the majority of the Supreme Court of Canada held that the Province of Manitoba was not competent to prohibit the pollution of waters flowing into the Province where the act of pollution occurred outside the Province. Pigeon J., speaking for Martland and Beetz JJ. held:66

\footnotetext{
It seems clear that a province, as owner of inland fisheries in its territory is entitled to legislate for the protection of its property. However, in respect of injury caused by acts performed outside its territory, I cannot accede to the view that his can be treated as a matter within its legislative authority when these acts are done in another province any more than when they are accomplished in another country.
}

However the dissenting Justices Laskin, Judson and Spence held that the purpose of the legislation was to affect civil rights in the Province of

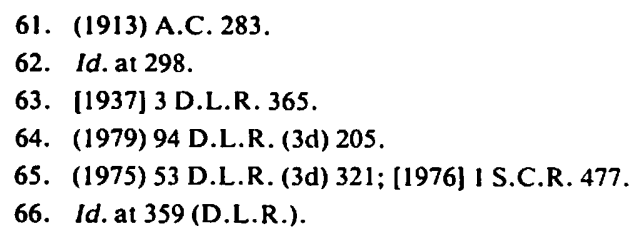


Manitoba and that since any extra-territorial effect was merely incidental, the legislation was intra vires. ${ }^{67}$

Depending on which line of reasoning is followed, a court may not be able to give ef fect to the limited partnership legislation of the forum if the act complained of occurs outside its jurisdiction. If the traditional view of the majority in Interprovincial predominates, then even a court in the jurisdiction in which the limited partnership was formed would not apply the legislation so as to affect rights which arise outside the province. If the dissenting view in Interprovincial takes hold, then a court might be inclined to overlook the fact that the act occurred outside the province if the purpose of the legislation is to only affect civil rights within the province.

\section{OFF-SHORE ACTIVITIES}

We have ascertained that the province is only competent to legislate over acts which occur within its boundaries, but we have not yet determined where its boundaries end. It now seems well established that unless the British Crown has conferred territory extending beyond the low water mark before the particular province entered into confederation, ${ }^{68}$ the jurisdiction of the province will end at the low water mark. Since a province is not a state and is therefore not competent under international law to acquire land through legislation it follows that the province will not have any legislative jurisdiction over off-shore activities. This was the approach taken by the Supreme Court of Canada in Re Ownership of Offshore Mineral Rights ${ }^{69}$ and subsequently in Re Mineral and Natural Resources of the Continental Shelf. ${ }^{70}$ In the latter case, the court summarized and adopted the ef fect of the former:

This Court held, on its analysis of R. v. Keyn [1876] 2 Ex.D. 63 and other authorities, that at common law the realm ends at low water mark such that the Crown has no property, in the common law sense, below the low water mark unless expressly claimed. There being no such claim in respect of British Columbia prior to 1871 , and no alternative boundaries since 1871 , the Court decided the territorial sea was outside British Columbia. It followed that British Columbia had no legislative jurisdiction either. It was Canada that was in the position to acquire the property in the territorial sea recognized by international law."

67. This approach was also followed in Underwood, McLellan \& Associates Limited v. Association of Professional Engineers of Saskatchewan [1980] 1 W.W.R. 43 where legislation which authorized inquiry by a committee into acts of professional misconduct occurring outside the Province was intra vires because the purpose of the statute was to protect the rights of citizens within the Province; see also Ladorev. Bennett [1939] A.C. 468 (P.C.).

68. In the Straits of Georgia Reference [1977] 1 B.C.L.R. 97 the British Columbia Court of Appeal held that the waters between the mainland and Vancouver Island are part of the Province of British Columbia for proprietary and legislative purposes, since the Imperial Act of 1866 had defined British Columbia as extending to the Pacific Ocean.

69. (1968) 65 D.L.R. (2d) 353.

70. Decision rendered by the Supreme Court of Canada on March 8, 1984.

71. Presumably these recent constitutional decisions have overruled cases such as The King v. Conrad(1938) 12 M.P.R. 588 and R.v. Burt (1932) 5 M.P.R. 112 where the courts gave effect to provincial legislation over events occurring off-shore. 
Therefore only Parliament is competent to enact legislation relating to activities occurring in the territorial sea. ${ }^{72}$

The number of federal statutes which extend beyond the low water mark are limited. ${ }^{73}$ The result is that there is very little legislative authority pertaining to property and civil rights off-shore. One statute of potential significance is the Canada Shipping Act. $^{74}$ Section 638 of the Act addresses the question of liability where damage is caused to a vessel or any cargo, freight, or property on board as a result of a collision between two or more vessels where each is at fault. Subsection four provides an exception to liability:

(4) Nothing in this section affects the liability of any person under a contract, or shall be construed as imposing any liability upon any person for which he is exempted by any contract or by any provision of law, or as affecting the right of any person to limit his liability in a manner provided by law.

Similarly section 639 addresses liability where there has been a loss of life or personal injury where the fault of more than one vessel is involved. Sub-section (2) provides a defence:

(2) Nothing in this section shall be construed as depriving any person of any right of defence on which, independently of this section, he might have relied in any action brought against him by the person injured, or any person or persons entitled to sue in respect of such loss of life, or to affect the right of any person to limit his liability, in cases to which this section relates, in the manner provided by law.

These sections are ambiguous, insofar as they do not attribute any meaning to the phrase "in the manner provided by law." Although it may certainly be argued that a limited partner has limited his liability in the manner provided by law, it is not clear that Parliament was referring to any manner provided by law because the definite article has been used. Furthermore, the section does not appear to grant any new defences to liability but is merely permissive in that it allows the defendant to rely on any defences which he would have had independent of the section. In other words, the defendant would still be required to demonstrate that the limited partnership has effect outside the jurisdiction in which it was formed.

In any event these provisions would only apply where vessels are involved. The term is defined in the Act to include "any ship or boat or any other description of vessel used or designed to be used in navigation." 75 The description of vessel has been the subject of judicial decisions which consider a variety of factors in determining whether the structure is a vessel, the most predominant of which is the element of navigation

72. However the Canadian government appears to have an obligation to extend Nova Scotia laws off the coast of Nova Scotia by virtue of s. 17(d) of the Canada-Nova Scotia Offshore Oil and Gas Resource Management and Revenue Sharing Agreement, March 2, 1982.

73. See A.L.C. de Mestral, "The Law Applicable to the Canadian East-Coast Offshore" (1983) 21 Alta. Law. Rev. 63 at 64-5.

74. R.S.C., S-9.

75. S. 2. 
whether through tow or self-propulsion. ${ }^{76}$ It is therefore questionable whether much of the equipment used in off-shore oil and gas development and exploration will qualify under these provisions.

In the absence of both applicable federal and provincial legislation, there is a body of law known as Canadian admiralty law which will determine the legal issues arising from of -shore activities whether on the territorial sea or the high seas. ${ }^{77}$ The body of admiralty law is usually referred to as the common law of the sea as administered by Canadian courts. ${ }^{78}$ Its nature and effect is more specifically described in the judgment of the Supreme Court of Canada in Triglav v. Terrasses Jewellers Inc. ${ }^{79} \mathrm{Mr}$. Justice Chouinard in delivering judgment on behalf of the Court adopted a passage from Jackett C.J. of the Federal Court in Associated Metals and Minerals Corp. v. The Chip "Evie W' and Aris Steamship Co.: ${ }^{80}$

Without being more precise and realizing that there are many aspects of admiralty law that are obscure, I am of opinion that the better view is

(a) that there is, in Canada, a body of substantive law known as admiralty law, the exact limits of which are uncertain but which clearly includes substantive law concerning contracts for the carriage of goods by sea;

(b) that admiralty law is the same throughout Canada and does not vary from one part of Canada to another according to where the cause of action arises;

(c) that admiralty law and the various bodies of "provincial law" concerning property and civil rights co-exist and overlap and, in some cases at least, the result of litigation concerning a dispute will differ depending on whether one body of law or the other is involved; and

(d) that admiralty law is not part of the ordinary municipal law of the various provinces of Canada and is subject to being "repealed, abolished or altered" by the Parliament of Canada.

Although admiralty law is considered to be homogenous through Canada and to be not part of the laws of the provinces but subject only to the will of Parliament, the Court was unable to determine the exact limits of the substantive law. Le Dain J., in Skaarup Shipping Corp. v. Hawker Industries Ltd. $^{81}$ makes the argument that there exists a "necessary substantive federal law to support an exercise of jurisdiction". Since civil

76. N.H.B. v. St. John Shipbuilding (1982) 43 N.R. 15. Other factors reviewed include:

(i) ability to float in or upon water (See The Mac (1882) 7. P.D. 126),

(ii) whether structure built for use on water (St. John Shipbuilding),

(iii) involvement of men and/or goods on the structure for the purpose of transportation, carriage or navigation ( $T h e \mathrm{Mac}$ ).

Other authorities include Dome Petroleum Ltd. v. Hunt International Petroleum [1978] 1 F.C. 11; R. v. Gulf Aladdin [1976] 27 C.C.C. (2d) 562; Fort William v. McNamara Construction [1957] O.W.N. 466, [1957] 10 D.L.R. (2d) 625; R. v. Teleneski [1983] C.S.P. 1038.

77. In order to exercise its admiralty jurisdiction, a Canadian court must acquire jurisdiction where the act complained of occurs on the high seas. This usually involves acquiring control over the res. See Mayer, Admiralty Law and Practice (1916) p. 28; section 22(3) of the Federal Court Act, R.S.C. 1970, c. 10 as amended gives the court jurisdiction over "all ships whether Canadian or not and wherever the residence or domicile of the owners may be."

78. Castel, Conflict of Laws, supra n. 5 at 659.

79. [1983] 1 S.C.R. 283.

80. [1978] 2 F.C. 710 at $716-17$

81. See also Antares Shipping Corp. v. The Ship "Capricorn", [1980] I S.C.R. 553, 30 N.R. 104 (per Ritchie J.) and N.H.B. Shipping, supra n. 73. 
remedies may be granted by the Federal Court in exercising its admiralty jurisdiction, ${ }^{82}$ it must apply substantive law relating to property and civil rights. If there is such a thing as federal common law, it is unlikely that it would include the concept of the limited partnership which, as we have seen, is a creature of statute. It is therefore not at all certain that a limited partner would be able to maintain its limited liability in the territorial or high sea where provincial legislation is without effect.

\section{CONCLUSION}

Since a limited partnership is not a legal entity, but merely an arrangement of agency, it does not appear that the limited partner can argue that he is a person separate from the firm in the same way that a shareholder is distinct from the corporation. The limited partner is a principal to the general partner and, in the absence of legislation to the contrary, would be personally liable to third parties for all acts within the ostensible authority of the general partner. However, provincial legislation, which gives effect to the limited liability, cannot under Canadian constitutional law effect civil rights beyond provincial boundaries. Foreign jurisdictions are under no obligation to recognize the legislation giving rise to the limited partnership. It is therefore by no means clear that the limited partner will be able to maintain his limited liability where the act or transaction of the partnership is subject to the laws of a foreign jurisdiction.

Common law principles require that the law of the jurisdiction governing the interaction between the agent and the third party be applied to the relationship between the principal and third party. Since the general partner is the agent of the limited partner, it follows that this reasoning will also apply to limited partnerships. Once the general partner engages in activities on behalf of the limited partnership outside the jurisdiction of formation, then unless the parties intend otherwise, or the limited partnership has been duly registered as such in the foreign jurisdiction, the limited partner will be subject to the laws of that jurisdiction which may not recognize his limited liability. However, it may be possible for the limited partner to argue that his status as a limited partner should be recognized by the foreign jurisdiction, although he will have much greater difficulty convincing the court to enforce the limited liability as an incident of that status.

Not only can provincial legislation not guarantee the limited liability of the limited partner for acts of the general partner which occur in other jurisdictions, but of fshore activities will also not necessarily fall subject to provincial legislation. Drilling activities occurring in either the territorial or international waters will be subject, in the absence of relevant federal legislation, to the common law of the sea as administered by Canadian courts. Since limited partnerships are creatures of statute, and there are no reported cases where the concept of the limited partnership has been recognized in admiralty law, it is far from certain that the liability of the limited partner for off-shore partnership activities will be limited to the extent of its investment.

82. Federal Court Act, R.S.C. 1970, c. 10, s. 22(2). 